\title{
DAMPAK KONFLIK TERHADAP PEREKONOMIAN MASYARAKAT DI NEGERI MAMALA DAN MORELLA
}

\author{
Farid Naya \\ Fakultas Syariah dan Ekonomi Islam \\ Email: faridnaya12345@gmail.com \\ Rosita Malawat \\ Mahasiswa Jurusan Muamalah IAIN Ambon
}

\begin{abstract}
ABSTRAK
Penelitian ini bertujuan untuk menemukan jawaban atas dua pertanyaan penelitian. Pertama, mengapa konflik terus-menerus terjadi pada kedua masyarakat tersebut? Kedua, bagaimana konflik yang terus-menerus terjadi berdampak pada perekonomian kedua masyarakat tersebut? Penelitian ini menggunakan metode penelitian kualitatif (qualitavie research method) dengan pendekatan verstehen atau understanding untuk menggali dari dalam (Inside View) nilai atau makna yang bersumber dari subjek penelitian melalui individu-individu dan dinamika konflik di negeri Mamala dan Morella, serta bagaimana dampaknya bagi perekonomian kedua masyarakat pada kedua negeri tersebut. Hasil penelitian menunjukan bahwa (1) Konflik merupakan suatu akibat yang ditimbulkan dari interkasi sosial dengan struktur sosial yang terbangun di dalam masyarakat kedua negeri tersebut. Aspek historisitas dari kedua masyarakat menjadi salah satu pemicu adanya intensitas konflik. Kleim legitimasi adat mewarnai kesadaran masyaramat kedua masyarakat tersebut. (2) Konflik yang terus mengalami intensitas telah memberikan dampak negatif bagi kedua masyarakat tersebut. Salah satunya adalah tingkat kemahalan dari proses penjualan produk lokal masyarakat. Mulai dari produksi pengangkapan ikan oleh nelayan pada kedua masyarakat.
\end{abstract}

Kata kunci: dampak konflik, perekonomian masyarakat.

\section{ABSTRACT}

This study aims to find answers to two research queation. Firt, why the conflik continue to occur at both the community? Second, how the conflikt persistent impact on the economy of these societies? This study uses qualitative research methods (qualitavie research method) approach verstehen or understanding to explore from the inside (Inside View) value or meaning derived from the subject of research by individuals and the dynamics of conflict in the country Mamala and Morella, as well as how the economic impacts both communities in both countries. Data obtained through observation, interview and documentation. Data analysis begins with making abstraction, making categorization, coding, data validity checking, and interpret data and draw conclusion. The results showed that, first, the conflict is a consequence arising from social interaction with a social structure that is built in the community both countries. The second aspect of the historicity of the country to be one trigger their intensity conflict. Cleim legitimacy of customary 


\section{Tahkím}

Vol. XIV, No. 2, Desember 2018

dyeing masyaramat awareness of both countries. Second, conflicts which continue to experience the intensity, has a negative impact on both the community. One is the level of the costliness of the local community product sales. Start of production of fish by fishermen arrests in both societies.

Keyword: impact of the conflict, economic community

\section{Pendahuluan}

Sejak tahun 1997 Indonesia dilanda krisis moneter disertai dengan fluktuasi kondisi ekonomi dan politik yang tidak menentu, telah mengiring indonesia menuju konflik nasional, baik secara struktural maupun horizontal. semenjak runtuhnya rezim orde baru tahun 1998 yang di gantikan oleh B.J. Habibie yang diharapakan dapat menata sisitem politik yang demokrasi berkeadilan. ${ }^{1}$

Pada waktu itu Indonesia sangat rentan dengan perpecahan, terjadi berbagai gejolak konflik di berbagai daerah, salah satunya konflik yang terjadi di maluku yang di sinyalir oleh banyak kalangan adalah konflik bernuansa SARA. dalah pertikaian suku dan pemeluk agama islam dan kristen. Peristiwa kerusuhan diawali dengan pertikaian antardua pemuda yang berbeda agama sehingga belarut dan berhujung dengan terjadinya kerusuhan. Impliksasi- implikasi kepentingan politik elite nasional, elite lokal dan militer-militer juga diduga menyulut terjadinya konflik horizonttal sehingga sulit mencari penyelesaian yang lebih tepat. Bahkan, terkesan pihak keamanan polri lamban menangani konflik tersebut. Sehingga konflik terjadi belarutlarut yang memakan korban jiwa dan harta. ${ }^{2}$

Konflik merupakan suatu hal yang sering dialami oleh individu dan kelompok. Dalam sejarah kehidupan manusia konflik merupakan bagian dari kehidupan yang tak pernah terpisahkan Konflik merupakan suatu dilema yang dialami individu atau kelompok. Selama ini kebanyakan orang memandang konflik dalam dua hal, yaitu sebagai hal yang natural, normal, dibutuhkan,dan tak dapat dielakan dan sebagai suatu problem yang harus diatasi. Namun selama ini image terhadap konflik terkesan negatif, artinya konflik selalu diidentik dengan permasalahan, kekerasan, tidak menyenangkan, penderitaan, dan perang. ${ }^{3}$

Pendiri negara Indonesia sejak semula sudah menyadari bahwa negara ini adalah negara kepulauan yang majemuk baik sistem politik dan sistem hukum maupun sistem sosial ekonomi budaya dan agama. Daerah kesatuan masyarakat hukum adat seperti daerah-daerah yang ada di Maluku pada umumnya, dengan tujuan untuk mewujudkan kesejahteraan, ketertiban dan keamanan masyarakat. Maka dibutuhkan peran aktif dari seluruh elemen masyarakat untuk mampu mengembangkan potensi

\footnotetext{
${ }^{1}$ Sakai, Minako. Konflik sekitar Devolusi Kekuasaan Ekonomi dan Politik: Suatu Pengantar, (The University of New South Wales, 2005), h. 20

${ }^{2}$ Ibid., h. 47

${ }^{3}$ Ibid., h. 21
} 


\section{Tahkím}

Vol. XIV, No. 2, Desember 2018

yang ada, karena hal ini telah menjadi tangung jawab bersama masyarakat dan pemerintah. $^{4}$

Konflik horizontal antara negeri Mamala dengan Morela yang diawali pada saat masyarakat kedua negeri merayakan upacara adat "Pukul Sapu 6 sya'wal 1620 H". Konflik yang terjadi pada hari kamis 24 November 2005 telah memakan korban jiwa, harta benda dan meluputkan perekonomian masyarakat, rasa dendam dan kecemburuan masih terdapat dalam diri tiap-tiap individu kedua masyatakat dan menyebapkan konflik yang berkelanjutan pada tahun-tahun berikutnya 2008, sampai 2013, dan sampai pada saat sekarang ini ketegangan sosial masi menyelimuti kehidupan kedua masyarakat negeri Mamala dan Morela. Akibat konflik yang berkepanjangan ini sehingga mengundang perhatian publik dengan seribu tanda tanya,mengapa hal seperti ini terjadi?. Padahal kedua negeri yang terlibat konflik tersebut masih berasal dari satu garis keturunan (genealogis) orang basudara yang konon pernah hidup bersama-sama dalam satu negeri.

Dalam konteks konflik horizontal antara negeri adat, seperti yang terjadi pada beberapa kurun waktu terkahir di negeri Mamala dan Morela, apa yang disebut sebagai konflik antar negeri adat merupakan sebuah realitas pada masyarakat Maluku yang memiliki latar belakang budaya tertentu. Konflik semacam ini pun dinilai sebagai dampak konflik kemanusiaan yang terjadi di maluku selama kurang lebih empat tahun, yang berpengaruh terhadap sistem kesatuan hidup masyarakat adat di Jazirah Leihitu dengn terputusnya satu tali generasi (one lost generation). ${ }^{5}$

Konflik antara negeri Mamala dan Morela merupakan realitas yang sudah berpuluh tahun mewarnai hubungan antara kedua negeri, secara historis masyarakat kedua negeri tidak mengetahui secara pasti kapan pertamakali terjadinya konflik antara negeri Mamala dan Morela, namun yang masih segar dalam ingatan masyarakat kedua negeri bahwa konflik ini berlangsung silih-berganti telah lebih dari dua puluh lima tahun, atau satu generasi manusia, diantaranya pada tahun 1982, 1984, 1996, 2005, 2008. Dan yang terakhir pada tahun 2013, yang sampai pada saat sekarang ketegangan masih mewarnai kehidupan kedua masyarakat negeri Mamala dan Morela.

Negeri Mamala yang $80 \%$ masyarakatnya berprofesi sebagai petani, kini sudah tidak bisa lagi memanen hasil hutan mereka yang berbatasan dengan negeri Morela akibat aksi pembunuhan yang sering di lakukan oleh masyarakat negeri morela di hutan perbatasan kedua negeri, karena msyarakat negeri mamala tak lagi berkebun di hutan perbatasan maka banyak hasil hutan yang di curi dan tanaman-tanaman sengaja di tebang misalnya cengkeh, manggis, pala, hal ini tentunya mengurangi kuantitas

\footnotetext{
129

${ }^{4}$ Soejono Soekanto Pengantar Sosiologi Kelompok (Cet.VI, bandung: Remaja Karya 2006), h.

${ }^{5}$ J. Sahalessy, "Peran Latupati Sebagai Lembaga Hukum Adat," Jurnal Sasi, Vol. 17 No.3, 2011, h. 46 .
} 


\section{Tahkím}

Vol. XIV, No. 2, Desember 2018

jumlah tanaman yang menunjang perekonomian masyarakat negeri mamala yang telah terhimpun dalam suatu organisasi pemerintah dalam bidang tani di tingkat desa (gapoktan) dan tanaman lainnya, padahal perbuatan tersebut sangat di larang oleh agam Islam.

Sama halnya dengan negeri Morela yang $80 \%$ masyarakatnya berpropesi sebagai nelayan, kini sudah sulit untuk menjual hasil tangkapannya. Sebab jalan yang telah diblokade oleh negeri Mamala sehingga akses untuk menjalankan roda perekonomian negeri Morela semakin sulit. Hak-hak mereka untuk melangsungkan hidup seperti telah dibatasi, bahan-bahan pangan/sembako sebagai kebutuhan pokok masyarakat yang biasanya diangkut melewati jalur darat, kini terpaksa harus di angkut melalui jalur laut dan memakan biaya yang cukup besar.

Dalam Islam, memelihara jiwa, harta, keturunan serta akal dari kerusakan adalah merupakan tujuan disyari'atkannya hukum oleh syari' (Allah) yang dalam teori hukum Islam dikenal dengan maqashid al-syari'ah, oleh karenanya itu Islam melarang segala tindakan-tindakan yang dapat menimbulkan kerusakan-kerusakan yang berlebihan dalam peperangan/konflik, hal itu dapat ditemukan dalam Al-Qur'an dan hadis yang merupakan sumber hukum utama Islam.

Konflik yang kerap kali terjadi sering menyebabkan korban jiwa demi kepentingan kelompok. Sedangkan dalam Islam ditegaskan bahwa membunuh sesama Muslim itu sama halnya dengan membunuh semua Manusia. Dengan mudahnya pertumpahan darah terjadi, permasalahan kecil berujung pada perpecahan dan pembantaian. Kita saksi kan konflik yang terjadi di negeri Mamala dan Morela dalam beberapa tahun terakhir ini, banyak harta benda yang rusak bahkan korban jiwa tak dapat terelakan hanya karena kesalahpahaman di antara mereka sehingga melupakan aturan Agama. ${ }^{6}$

Berbagai macam langkah yang telah ditempuh oleh pemerintah untuk menyelesaikan konflik antara warga negeri Mamala dan Morela telah dilakukan melalui mediasi maupun lembaga formal lainya, namun hasilnya tidak dapat menuntaskan konflik sosial yang di hadapi, pendekatan agama (Agama islam) telah di tempuh untuk menyelesaikan konflik sosial antar ke dua negeri ini, namun hasilnya tak bertahan lama seperti yang diharapakan. Perubahan yang dihadapi masyarakat negeri Mamala-Morela sampai saat ini berdampak dalam semua aspek kehidupan, terutama aspek perekonomian. Penulis merasa tertarik untuk membahas permasalahan tersebut dalam tulisan ini dengan permasalahan (1) bagaimana dinamika konflik yang terjadi antara negeri Mamala dan Morella?; dan (2) bagaimana dampak konflik terhadap perekonomian masyarakat di negeri Mamala dan Morella ?

\footnotetext{
${ }^{6}$ Masdar Farid Mas'udi, Agama dalam Konflik Sosial, dalam M.Imdadun Rahmat ,Islam Pribumi: Mendialogkan Agama Membaca Realitas, ( Cet. II, jakarta:Erlangga, 2003), h. 80
} 


\section{Tahkím}

Vol. XIV, No. 2, Desember 2018

\section{Kajian Riset Sebelumnya}

Dalam konteks permasalahan konflik yang sering terjadi dalam kehidupan masyarakat Maluku, khususnya Negeri Mamala dan Morela Kecamatan Leihitu Kabupaten Maluku Tengah, tidak terlalu banyak penelitian yang mengkaji permasalahan konflik yang di maksud.

Penelitian yang relevan di antaranya tesis karya Supiyat Hupea, "Modal Sosial dalam Penyelesaian Konflik, Studi Tentang Resolusi Konflik Antar Desa di Kecamatan Leihitu.”. Dalam tesis tersebut dibahas tentang aspek dan gejala-gejala hingga timbul konflik di Leihitu, dampak dan perubahan sosial pasca konflik serta resolusi mengenai penyelesaiannya. ${ }^{7}$ Hal senada Soerjono Soekanto dalam bukunya berjudul Pengantar Sosiologi Kelompok. Demikian juga Abdul Syani dalam bukunya Sosilogi kelompok dan masalah social. Dalam buku tersebut secara garis besar membahas tentang masalah-masalah sosial yang terjadi pada masyarakat, serta penyebap-penyebap konflik sosial yang terjadi antar individu dan masyarakat. ${ }^{8}$ Namun demikian tidak membahas permasalahan dalam tulisan ini.

\section{Konflik}

Konflik adalah suatu kenyataan hidup, tidak terhindarkan dan sering bersifat kreatif. Konflik terjadi ketika kepentingan maupun tujuan masyarakat tidak sejalan. Berbagai perbedaan pendapat terjadi namun konflik dapat diselesaikan tanpa adanya kekerasan dan bahkan sering menghasilkan situasi yang lebih baik bagi sebagian besar atau semua pihak yang terlibat. Konflik kemungkinan akan selalu ada, apalagi karena memang merupakan bagian dari keberadaan dalam kehidupan. Dari tingkat mikro, antar pribadi masyarakat dan negara, semua bentuk hubungan manusia sosial, ekonomi dan kekuasaan mengalami pertumbuhan, perubahan dan konflik. Konflik timbul karena ketidakseimbang-an antara hubungan-hubungan tersebut.

Menurut Nicholson sebagaimana dikutip oleh Abraham bahwa konflik dapat diartikan sebagai interaksi antara sedikitnya dua individu atau kelompok yang memiliki tujuan berbeda. Perbedaan ini secara umum merupakan ultima dari perbedaan pikiran, perkataan dan perbuatan. Perbedaan pandangan dan tujuan sering dipandang sebagai masalah yang hanya dapat diselesaikan jika kita semua pihak memiliki maksud yang sama, atau ketika suatu pandangan lebih kuat dari pada pandangan yang lain. ${ }^{9}$ Kemungkinan lainnya, perbedaan-perbedaan itu dapat dilihat sebagai sumber daya

\footnotetext{
${ }^{7}$ Supiyat Haupea, Modal Social Dalam Penyelesaian Konflik, Studi Tentang Resolusi Konflik Antar Desa Di Kecamatan Leihitu (Tesis), 2008

${ }^{8}$ Abdul Syani, Sosiologi Kelompok dan Masalah Sosial, (Cet. 2, Jakarta: Fajar Agung, 1987), h. 27

${ }^{9}$ Abraham M, Francis, Moderenisasi di Dunia Ketiga Suatu Teori Umum Pembangunan, Yogyakarta: Tiara Wacana Yagya, 1992), h. 57-58
} 


\section{Tahkím}

Vol. XIV, No. 2, Desember 2018

yang menuntun ke arah pemahaman yang lebih luas terhadap suatu masalah dan perbaikan situasi yang sedang dihadapi.

Dua elemen kuat seringkali bergabung dalam sebuah konflik yaitu Identitas dan Distribusi. Identitas diartikan sebagai mobilisasi orang dalam kelompok-kelompok identitas komunal yang berdasarkan atas RAS, agama, kultur, bahasa dan seterusnya. Ketika distribusi yang dianggap tidak adil dilihat bertepatan dengan perbedaan identitas (dimana suatu kelompok agama kekurangan sumber daya tertentu yang didapat kelompok lain), kita menemukan potensi konflik. Kombinasi antara faktor-faktor yang berbasiskan identitas secara kental dengan persepsi yang lebih luas tentang ketidakadilan ekonomi dan sosial seringkali menghidupkan apa yang kita sebut sebagai "konflik yang mengakar". Karakteristik yang paling menonjol dari konflik internal adalah tingkat ketahanannya. Hal ini timbul karena seringkali dasarnya terletak pada isu identitas; istilah konflik etnis sering digunakan. Etnisitas adalah konsep yang luas mencakup banyak sekali elemen: RAS, kultur, agama, keturunan, sejarah, bahasa dan seterusnya. Tetapi pada dasarnya merupakan isu identitas. Seringkali faktor-faktor yang berhubungan dengan identitas ini bercampur dengan konflik atas pendistribusian sumber daya seperti wilayah, kekuasaan ekonomi, prospek lapangan kerja. Konflik juga banyak dipahami sebagai suatu situasi dimana terjadi persaingan untuk memenuhi tujuan yang tidak selaras dari kelompok- kelompok yang berbeda. ${ }^{10}$ Melalui penelusuran definisi tersebut di atas, dapat disimpulkan bahwa konflik dapat terjadi kapan saja dan dimana saja ketika benturan pikiran, perkataan dan perbuatan tidak menemukan jalan keluar oleh individu atau kelompok yang tengah berinteraksi.

Arkoun dalam Syaukani mengatakan bahwa pembentukan hukum islam dalam asas teori tertinggi dapat diklasifikasikan pada persoalan Agama, sebagai pondasi dasar umat Islam mempunyai resolusi yang sangat kental dengan sakralisasi kehidupan manusia, sebagai pandangan dan peta tujuan manusia dalam mengaplikasikan konsepkonsep yang telah diwahyukan oleh Allah. swt. kepada hamba-Nya dengan berbagai anjuran dan larangan yang harus diimplementasikan dalalm kehidupan sosialnya sebagai paradigma yang melekat dan membentuk karakter manusia menjadi lebih baik. Secara prinsip agama adalah berasal dari dua kata yang terpisah, yaitu "a" bemakna tidak, dan "gama" mempunyai arti kacau. Artinya bahwa, agama adalah tidak menjadikan kacau dalam kehidupan ummatnya, agama menjadi panduan hidup dan pedoman kehidupan untuk berlaku baik, bijaksana, tolong menolong, kejujuran, dan prinsip-prinsip kebaikan yang diajarkan didalamnya. ${ }^{11}$

Bertolak dari penjelasan diatas, maka konflik yang sering terjadi di Maluku khususnya pada masyarakat Negeri Mamala dan Morela di Kecamatan Leihitu, itu

\footnotetext{
${ }^{10}$ Ibid., h. 59

${ }^{11}$ Imam Syaukani, "Hakikat Hukum Islam:Antara Divine Law Dan Man-Made Law". Ulumuddin, Vol. VI, Tahun IV, Januari-Juni 2010, h. 500.
} 


\section{Tahkím}

Vol. XIV, No. 2, Desember 2018

terjadi akibat adanya kesenjangan-kesenjangan sosiala dan ketidak seimbanagan dalam individu-individu maupun kelompok kedua negeri. Konflik Negeri mamala dan morela telah terjadi berpuluh tahun lamanya, dapat di pandang sebagai suatu proses sosial yang disosiatif dengan tingkat kekarasan yang sangat tinggi dan memakan banyak korban, berbagai analisis telah di kembangkan dengan pendekatan yang berbeda-beda tentang penyebab konflik dimaksud.

Walaupun para sosiolog (antara lain Dahtendorf, alfian, Charles tilly), mengakatan bahwa, bila terjadi konflik dalam suatu masyarakat, maka harus dicari penyebabnya pada pemerintah atau otoritas, karena peran pemerintah sebagai biang konflik dan sebagai pendamai. Namun pendapat para sosiolog itu seakan tidak sesuai dengan kenyataan dan analisis yang di kembangkan. ${ }^{12}$ Brigjen Pol. Mudji Waluyono. mantan Kapolda Maluku, tahun 2008 telah menggunakan cara-cara pendekatan kepolisian sebagai mitra masyarakat dalam merajut damai di Negeri Mamala dan Morela, dalam bukunya mengungkapkan bahwa sejumlah indikator penyebab konflik mamala-morela, terdapat pada kenakalan remaja dan pengaruh minuman keras (miras). ${ }^{13}$

\section{Segiti Tiga Konflik}

Konflik biasanya mudah dilihat di permukaan saja, seperti jumlah korban yang ditimbulkan atau cara kedua belah pihak berkonfrontasi secara langsung. Untuk itu dibutuhkan pemetaan untuk mengetahui pihak-pihak yang terlibat konflik serta hal yang melatarbelakanginya. Selain pemetaan tersebut konflik juga bisa di lihat melalui pendekatan teori bawang merah, segitiga konflik dan garis waktu yang menceritakan perkembangan eskalasi konflik. ${ }^{14}$

Segitiga konflik berfungsi untuk mengetahui gejolak konflik yang terlihat dan yang taidak terlihat. konflik yang terlihat adalah proses terjadinya kekerasan itu sendiri serta dampak yang ditimbulkan. Gejolak konflik yang tidak terlihat antara lain disebabkan oleh kekerasan budaya dan kekerasan structural. Kekerasan budaya bisa berupa hokum adat, mitos, anarki, suku serta kebencian kuno, sedangkan kekerasan structural bisa berupa kemiskinan dan kebudayaan.

Konflik adalah tentang kehidupan, yang menunjuk langsung pada kontradiksikontradiksi sebagai menciptakan kehidupan dan menghancurkan kehidupan. Teori konflik harus ditempatkan pada tingkat ini secara fenomenologis. Kedekatnnya dengan esensi kehidupan dapat didiskusikan, tetapi aspek ini harus selalu hadir dalam wacana

\footnotetext{
${ }^{12}$ Samuel Waileruni, Membongkar Konspirasi di Baliki Konflik Maluku, (Jakarta: Yayasan Pustaka Obor Indonesia, 2011), h. 72-74

${ }^{13}$ Mudji Waluyo, Implementasi Polisi Mitra Masyarakat Dalam Merajut Damai MamalaMorela, Jurnal Sasi, Vol. 19, No. 03, h. 30-31

${ }^{14}$ M. Mukhsin Jamil, Mengelola Konflik Membangun Damai, Teori Strategi dan Implementasi Resolusi Konflik, h. 18
} 


\section{Tahkím}

Vol. XIV, No. 2, Desember 2018

yang sekarang akan dikembangkan tentang konflik. Jika konflik penting dalam kehidupan, maka kehidupan mungkin juga penting bagi konflik. ${ }^{15}$

Pada tingkat manifest, empiris, dan terlihat, partisipan konflik hanya dapat mengalami, mengamati perilaku, yang disebut Perilaku(P). Baik Sikap(S) dan Kontradiksi (K) berada pada tingkat laten, teoritis, dugaan. Ketiganya secara bersamasama membentuk segi tiga konflik.

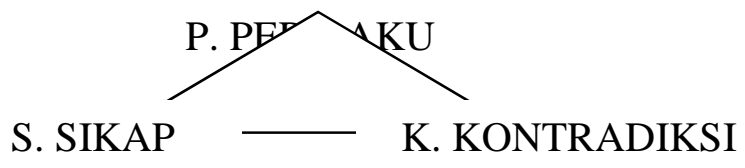

Gambar Segi Tiga Konflik, Jahon Galtung

Melalui segi tiga konflik ini, kita bisa melihat bahwa dalam sebuah konflik yang tidak simetris, kontradiksi ditentukan oleh pihak-pihak yang bertikai, hubungan mereka, dan benturan kepentingan antara mereka dalam berhubungan. Sikap yang dimaksud termaksud persepsi pihak-pihak bertikai dan kesalahan persepsi antara mereka dan dalam diri mereka sendiri. Jadi, ketika ada perbedaan persepsi atau ketidaksesuaian antara sikap dan perilaku dapat dikatan terjadi sebuah konflik. ${ }^{16}$

\section{Hubungan Antara Negeri Mamala dan Morela}

Dilihat dari asal-usul sejarah negeri Mamala dan negeri Morela, kedua negeri ini mempunyai hubungan sejarah yang sangat erat sekali. Jika telusuri, maka kedua negeri ini adalah merupakan satu negeri, nenek moyang mereka berasal dari 'Ula pokol" pausela salahutu simalopu, yang pada mulanya tiba di tempat tersebut. Uka Latu apel sebagai orang yang pertama tiba di tempat tersebut, kemudian di susul oleh teiga orang pengawalnya yaitu, Meten, Tuhe, dan Hity, tidak datang secara bersamaan namun secara bertahap, namun tidak di ketahahui kapan kedatangan mereka. Dari Ula Pokol kemudian mereka tersebar di beberapa tempat di daerah pegunungan, antara lain yaitu di gunung 'Iyal Uli, Amaela, dan Kapahaha'. Mereka mencari lokasi pemukiman di daerah pegunungan dengan tujuan untuk menghindari dari serangan musuh.

Pada tahun 1643-1644, atas perintah gubernur Gerard Demmer, Hena-hena kemudian di turunkan ke pesisir pantai seperti Soa Latu yang turun ke pesisir dan bergabung dengan Soa Loing dan Soa Polut. Sedangkan teleboang yang merupakan Uku dari Hausihul masih berada di sekitar benteng Kapahaha, setelah jatuhnya

\footnotetext{
${ }^{15}$ Johan Galtung, Studi Perdamaian, Perdamaian Dan Konflik, Pembangunan, Pembangunan Dan Peradaban, (Cet. 1; Surabaya: Aliansi Penerbit Interpenden, 2003), h. 160

${ }^{16}$ Ibid., h. 161
} 


\section{Tahkím}

Vol. XIV, No. 2, Desember 2018

kapahaha ketangan Belanda pada Tahun 1646, Hausihul di tempatkan berdekatan dengan Negeri Mamala. ${ }^{17}$

Hena-hena yang ada di bagian timur jazirah leihitu membentuk satu persekutuan yang di sebut "Uli Sailessy", yang terdiri dari Latu, Loing, Polut, Hausihul, dan Liang. Pada abad XVI-XVII, kedua negeri ini mulai hidup bersatu dan di perintahi oleh seorang Raja. Dasar pemersatu kedua negeri tersebut adalah dengan sebutan, dari "wae ume" (mamala) ke "wae tuwa" (morela), atau biasa disebut 'Latu He'hale (mamala) dan Latu He'hiya', (morela). Hal tersebut telah menunjukan bahwa Negeri Mamala dan Morela adalah merupakan satu negeri.

Tahun 1812 'Latu Manut' yang pada saat itu memerintah, kemudian menyerahkan kekuasaan atas Negeri Morela kepada 'Sabar Thenu.' Penyerahan kekuasaan atas negeri Morela itu mengakibatkan bertambahnya penduduk negeri Morela, dan usaha Belanda dalam menjalankan politik pecah belah. Penyerahan negeri Morela tersebut dikuatkan dengan 'surat keputusan'" atau 'baslouit" yang diserahkan oleh 'Latu Manut', kepada 'Latu Sabar Thenu' untuk menangani dan memerintah negeri tersebut. ${ }^{18}$

\section{Dinamika Konflik Yang Terjadi Antara Negeri Mamala dan Morella}

\section{Konflik Negeri Mamala dan Morela}

Konflik yang selalu hadir di dalam setiap pribadi maupun kelompok manusia adalah suatu realitas, sehingga dapat di terima sebagai kewajaran dan sangat biasa. Namun konflik menjadi tidak wajar dan tidak biasa bila konflik itu telah mengakibatkan banyak korban manusia (meninggal, cacat, kehilangan kasih sayang, kehilangan relasi sosial, kehilangan tempat hunian dan lain sebaginya), kehancuran berbagai sarana fisik dan nilai-nilai sosial. Konflik, menjadi tidak wajar dan tidak biasa bila konflik yang menimbilkan banyak korban, itu merupakn suatu konspirasi yang terjadi dalam suatu masyarakat yang cinta damai, menjunjung, menhargai, dan melaksanakan nilai-nilai kekeluargaan, persekutuan antar sesama. Juga konflik itu menjadi tidak wajar dan tidak biasa, bila masyarakat yang terlibat dalam konflik untuk saling membunuh, dan menghancurkan tanpa mengetahui dengan jelas penyebab dan manfaat dari konflik itu. ${ }^{19}$

Anak negeri Mamala dan anak Negeri Morela, telah memiliki bebagai pengalaman konflik dan turut terlibat di dalamnya, namun menyangkut konflik Mamala dan Morela dalam beberapa decade terakhir misalnya pada tahun 2005, 2008, 2013, dan sampai sekarang ini patut diterma sebagai konflik yang tidak wajar dan tidak biasa

\footnotetext{
${ }^{17}$ Haris Malawat, Hubungan antara Negeri Mamala dan Negeri Morela di Jazirah Leihitu Pulau Ambon, (Skripsi), 1994, h. 33-35

${ }^{18}$ Ibid., 36

${ }^{19}$ Samuel Waileruni, loc.cit.
} 


\section{Tahkím}

Vol. XIV, No. 2, Desember 2018

dalam kehidupan anak Negeri Mamala dan anak negeri Morela yang sudah terbiasa membangun suasana damai karena nilai-nilai budaya dan agama yang menjadi pedoman.

Konflik negeri Mamala dan Morela yang terjadi pada tanggal 24 november 2005, telah mengakibatkan korban jiwa dan harta benda, kurang lebih di perkirakan 5 (lima) buah Rumah hangus terbakar, serta banyak korban luka tenbak maupun luka akibat senjata tajam dan bom rakitan. Bukan seja itu, pada tahun 2008 bentrokan antar kedua negeri kembali terjadi, bentrokan yang terjadi pada hari sabtu tanggal 18 juni sekitar pukul 23.30 sampai pada, 19 juni Minggu dini hari, telah mengakibatkan 2 orang warga mengalami luka tembak dan beberapa warga lainya mengalami luka akibat serpihan bom rakitan serta 1 (satu) bangunan sekolah hangus terbakar. ${ }^{20}$

\section{Segi Tiga Konflik}

Konflik biasanya mudah dilihat di permukaan saja, seperti jumlah korban yang ditimbulkan atau cara kedua belah pihak berkonfrontasi secara langsung. Untuk itu dibutuhkan pemetaan untuk mengetahui pihak-pihak yang terlibat konflik serta hal yang melatarbelakanginya. Selain pemetaan tersebut konflik juga bisa di lihat melalui pendekatan teori bawang merah, segitiga konflik dan garis waktu yang menceritakan perkembangan eskalasi konflik. ${ }^{21}$

Segitiga konflik berfungsi untuk mengetahui gejolak konflik yang terlihat dan yang tidak terlihat. konflik yang terlihat adalah proses terjadinya kekerasan itu sendiri serta dampak yang ditimbulkan. Gejolak konflik yang tidak terlihat antara lain disebabkan oleh kekerasan budaya dan kekerasan structural. Kekerasan budaya bisa berupa hokum adat, mitos, anarki, suku serta kebencian kuno, sedangkan kekerasan structural bisa berupa kemiskinan dan kebudayaan.

Konflik adalah tentang kehidupan, yang menunjuk langsung pada kontradiksikontradiksi sebagai menciptakan kehidupan dan menghancurkan kehidupan. Teori konflik harus ditempatkan pada tingkat ini secara fenomenologis. Kedekatnnya dengan esensi kehidupan dapat didiskusikan, tetapi aspek ini harus selalu hadir dalam wacana yang sekarang akan dikembangkan tentang konflik. Jika konflik penting dalam kehidupan, maka kehidupan mungkin juga penting bagi konflik. ${ }^{22}$

Pada tingkat manifest, empiris, dan terlihat, partisipan konflik hanya dapat mengalami, mengamati perilaku, yang disebut P. Baik $\mathrm{S}$ dan $\mathrm{K}$ berada pada tingkat laten, teoritis, dugaan. Ketiganya secara bersama-sama membentuk segi tiga konflik.

Melalui segi tiga konflik ini, kita bisa melihat bahwa dalam sebuah konflik yang tidak simetris, kontradiksi ditentukan oleh pihak-pihak yang bertikai, hubungan

\footnotetext{
${ }^{20}$ Ibid.

${ }^{21}$ M. Mukhsin Jamil, Mengelola Konflik Membangun Damai, Teori Strategi dan Implementasi Resolusi Konflik, h. 18

${ }^{22}$ Johan Galtung, op.cit., h. 160
} 


\section{Tahkím}

Vol. XIV, No. 2, Desember 2018

mereka, dan benturan kepentingan antara mereka dalam berhubungan. Sikap yang dimaksud termaksud persepsi pihak-pihak bertikai dan kesalahan persepsi antara mereka dan dalam diri mereka sendiri. Jadi, ketika ada perbedaan persepsi atau ketidaksesuaian antara sikap dan perilaku dapat dikatan terjadi sebuah konflik. ${ }^{23}$

\section{Sebab-sebab Terjadinya Konflik}

Konflik Negeri Mamala dan Negeri Morela di Kecamatan Leihitu Kabupaten Maluku Tengah yang terjadi dalam beberapa kurun waktu terakhir ini, merupakan realitas yang sudah berpuluh tahun mewarnai hubungan antara kedua negeri. Konflik silih berganti itu telah berlangsung lebih dari dua puluh lima tahun, atau satu generasi manusia.

Berdasarkan penelitian yang di lakukan di Negeri Mamala dan Morela, kemudian dapat di temukan beberapa faktor yang menimbulkan masalah sebagai titik picu proses terjadinya konflik, antara lain sebagai berikut:

1. Fanatisme adat (ego cultur)

Fanatisme adat (ego cultur) merupakan suatu hal penting dan sangat berpengaruh terhadap timbulnya konflik antar negeri adat di Kecamatan Leihitu tak terkecuali negeri mamala dan morela yang merupakan bagian dari kecamatan tersebut. Hal semacam ini sering dijadikan sebagai isu utama pemicu konflik antar negeri, yang berpengaruh terhadap terkikisnya budaya dan adat istiadat. Konflik antar negeri sebagai akibat dari fanatisme adat harus dipelajari secara khusus agar kedepan tidak timbul konflik serupa dengan alasan yang sama. Charles Taylor mengatakan bahwa masingmasing agama dan budaya menuntut pengakuan dan penghargaan semua orang.

\section{Minuman Keras (miras)}

Dari sekian konflik yang terjadi pada negeri-negeri adat di Kecamatan Leihitu lebih banyak di picu oleh minuman keras. Hal ini dibuktikan dengan tingginya angka kriminalitas menurut data dari pihak kepolisian (Polsek Leihitu). Hal ini disukung dengan semakin maraknya perdagangan minuman keras di Kecamatan Leihitu yang sangat mempengaruhi kehidupan masyarakat Negeri Mamala dan Morela. Dapat dibayangkan berapa jumlah pecandu miras oleh masyarakat kedua negeri. Jumlah pecandu ini akan terus meningkat dan lebih banyak terlihat pada acara hiburan tertentu yang sangat berpeluang terhadap suatu tindak krriminal baik antara sesama pecandu atau dengan masyarakat yang pada akhirnya akan menimbulkan konflik antar negeri.

\section{Kenakalan Remaja}

Kenakalan remaja telah menjadi isu lokal yang mempengaruhi tingkat kamanan dalam sebuah masyarakat. Akibat dari kenakalan remaja ini biasanya akan menjalar sampai kepada terjadnya tawuran antar kelompok dan kemudian menjadi

\footnotetext{
${ }^{23}$ Ibid., h. 161
} 


\section{Tahkím}

Vol. XIV, No. 2, Desember 2018

antar negeri. Ada suatu konsekuensi dari solidaritas yang kuat antara para remaja dan masing- masing negeri, ini adalah suatu fenomena buruk yang sangat disesalkan. Dalam menyikapi setiap persoalan antara individu mereka tidak memikirkan latar belakang dan dampaknya terhadap masyarakat secara keseluruhan, sehingga akan melibatkan kelompok masyarakat yang lebih luas.

Tingkah laku seseorang (melanggar kaidah) ditentukan oleh sikapnya (attitude) dalam menghadapi suatu situasi tertentu. Sikap ini ditentukan oleh kesadaran subjektif akan nilai dan norma dari masyarakat atau kelompoknya. Nilai dan kelompok ini dihayati oleh indivdu dari dan dalam kebudayaan di mana dia dilahirkan dan di besarkan, seorang individu yang melanggar norma mempunyai sikap tertentu terhadap situasi yang diatur dalam norma yang bersangkutan. Sikap ini adalah hasil dari sosialisasi individu.

4. Masalah adat

Masalah adat merupakan salah satu faktor timbulnya konflik, tradisi adat 'baku pukul manyapu' yang dilaksanakan oleh kedua negeri setiap tahun sering dipermasalahkan oleh kedua negeri mamala dan morela. Masing-masing negeri mempertahankan acara adat tersebut sebagai implementasi adat yang sangat sacral sejak leluhur pada kedua negeri Mamala dan Morela.

\section{Penyelesaian Hukum}

Dalam kasus konflik antara Negeri Mamala dan Morela, interfensi penegakan hukum yang dialakukan oleh pemerintah dalam hal ini lembaga yuridis, belum begitu intensif, sehingga dalam bentuk penyelesaian yang di lakukan tidak menimbulkan efek jera di kalangan masyarakat. Ketika di teliti lebih mendalam, terjadinya konflik yang berkepanjangan antara Negeri Mamala dan Morela, di karenakan penyelesaian hukum yang dilakukan oleh pemerintah belum menyentuh basis nilai-nilai yang ada di dalam masyarakat kedua negeri.

Faktor-faktor psikologis yang ada dalam masyarakat sangat mempengaruhi tingkah laku individu dalam kaitannya dengan kepatuhan dan kesadaran akan hukum. Itu yang harus di perhatikan oleh pemerintah atau lembaga yuridis dalam usaha penyelesaian konflik antara Negeri Mamala dan Morela.

Dari kelima faktor faktor tersebut di atas, merupakan faktor feudal yang sering memicu konflik antara negeri mamala dan morela. Perkelahian antara negeri-negeri adat merupakan suatu abstraksi mental yang sudah di tanam sejak masa penjajah dulu, sehingga mengganggu proses interaksi sosial, budaya, dan stuktural masyarakat. Titik picu itu selalu di gerakan oleh faktor-faktor latent yang tidak tuntas penyelesaiannya, penanganan yang dilakukan oleh kepolisian dalam beberapa waktu lampau, hanya berhasil melakukan pencegahan terhadap konflik tetapi tidak menyelesaikan masalah 


\section{Tahkím}

Vol. XIV, No. 2, Desember 2018

secara tuntas antara kedua negeri mamala dan morela, sehingga penerapan hukum yang dilakukan tidak membentuk efek jera di kalangan masyarakat kedu negeri. ${ }^{24}$

\section{Analisis Proses Penyelesaian Konflik.}

Sebagai salah satu lembaga tertinggi dalam masyarakat, dalam menjalankan perannya untuk menyelesaikan konflik antar negeri di Kecamatan Leihitu khususnya negeri mamala dan morela, Pemerintah dan lembaga yudikatif selalu berupaya untuk menuju kepada perdamaian yang hakiki dengan semangat kearifan dan moral yang tinggi sesuai nilai- nilai (karakteristik), dasar perekat (idiologi) serta pemersatu (integritas) yang menunjukan lembaga ini sebagai identitas lembaga yang menpunyai tanggung jawab terhadap masyarakatnya. Selain pemerintah, kebudayaan local masyarakat Leihiitu (local culture identity), yang di wujudkan dalam suatu organisasi adat (latu pati) juga mempunyai peranan yang sangat penting dalam penyelesaian konflik negeri mamala dan morela.

Peranan pemerintah dan lembaga Latupati dalam penyelesaian konflik horizontal negeri mamala dan morela ini harus dijadikan sebagai saran-saran konstruktif dalam proses penyelesaian konflik yang terjadi, lembaga yudikatif atau aparat penegak hukum dan lembaga latu pati pada umumnya harus berupaya menemukan sebuah solusi dalam hal penyelesaian konflik mamala dan morela. Untuk menjalankan tugas moral tersebut, pemerintah sebagai lembaga tertinggi masyarakat, dan lembaga Latupati sebagai implementasi kearifan local masyarakat adat seharusnya menyusun beberapa langka sebagai pola penanganan yang terbagi kedalam empat tahap pertemuan menuju kepada perdamaian, yaitu:

1. Lembaga pemerintah dan Latupati bersama-sama Para Raja (Pemimpin Negeri).

Hal ini merupakan proses awal dari suatu perdamaian antar negeri adat di kecamatan Leihitu, sebagai bentuk kerja sama dari orang-orang yang mempunyai kepentingan dan tujuan-tujuan yang sesuai menuju kearah perundingan. ${ }^{25}$

2. Pemerintah dan Latupati dengan Staf Negeri (Saniri).

Yang dilakukan oleh pemerintah dan lembaga Latupati pada tahap ini bertujuan mengidentifikasi itikad baik (hati nurani) dari dua negeri untuk berdamai. Pertemuan ini dilakukan secara sepihak antara lembaga latupati dengan saniri negeri dengan cara mendatangi suatu negeri terlebih dahulu dan dilanjutkan ke negeri berikutnya. Dalam proses ini terjadi tawarr menawar antara pemerintah dan latupati dengan saniri dari negeri yang bertikai mengenai jalan keluar menghentikan konflik yang terjadi. Apabila telah dihasilkan kata sepakat maka hasil musyawarah ini ditawarkan kepada masyarakat untuk ditindaklanjuti secara bersama-sama atas dasar mufakat solidaritas dan itikad baik.

\footnotetext{
${ }^{24}$ J. Sahetapi, "Lembaga Latu Pati Sebagai Lembaga Hukum Adat dalam Penyelesaian Konflik di Kecamatan Leihitu." Jurnal Sasi, Vol. 17, No. 3, 2011, h. 21

${ }^{25}$ Ibid., h. 22.
} 


\section{Tahkím}

Vol. XIV, No. 2, Desember 2018

3. Pemerintah dan Latupati dengan Para Tokoh (Adat, Masyarakat, Agama dan Pemuda darri Negeri tang bertikai).

Hal ini merupakan tahap lanjutan dari pertemuan kedua yang dilakukan oleh pemerintah dan lembaga latupati. Tahap ini menggambarkan eksepsi (penerimaan) pihak ketiga oleh negeri yang bertikai, pemerintah dan latupati dalam keberadaannya dipandang sebagai suatu lembaga yang independen. Inilah kondisi pembatas yang penting jika salah satu pihak misalnya mengidentifikasikan untuk menrapkan pendekatan proses menjadi sangat kecil. ${ }^{26}$

4. Pemerintah dan Latupati dengan Seluruh Masyarakat (Saniri Besar) Negeri yang bertikai.

Tidak semua penyelesaian konflik antar negeri adat di Kecamatan Leihitu diakhiri dengan sumpah adat. Sumpah adat biasanya dilakukan sebagai wujud nyata dari suatu perdamaian antar negeri. Upcara adat ini dilakukan agar perdamaian ini dapat lebih mengikat secara moral bagi asyarakat Leihitu pada umumnya dan masyarakat Negeri Mamala dan Morela khususnya. Untuk itu peelaksanaan sumpah adat memiliki nilai tersendiri dalam mepertahankan dan mengawal perdamaian tersebut. Sesuai dengan kekuatan spiritual dan kultural yang dipercayai mempengaruhi pergaulan hidup antar masyarakat adat di negeri mamala dan morela, dan sebagai penjaga eksistensi identitas asli orang Maluku. Kekuatan mengikat perjanjian didasarkan pada asas yang tertuang dalam Kapata "Yale Hale Hatu, Hatu Hale Sei “ yang artinya barang siapa membalik batu (adat), batu atau adat tersebut balik menindis dia. Asas seperti ini dikenal dalam hukum internasional dengan asas "Pacta sunt servanda “

Sanksi yang diberikan terhadap negeri yang tidak mentaati keputusan kesepakatan suatu perjanjian perdamaian lembga Pemerintah dan latupati dapat berupa sanksi adat dan sanksi sesuai hukum negara. Terdapat beberapa jenis dan bentuk sanksi yang menjiwai hukum adat di negeri Mamala dan Morela yaitu:

\section{Sanksi tidak langsung}

Dalam penerapan sanski tidak langsung bagi mereka yang melakukan penyelewenangan terhadap suatu perjanjian perdamaian berupa pelanggaran atau kejahatan, maka sanksi itu dilandaskan pada pandangan hidup yang bersifat kosmis atau religious magis yang hakikatnya berpegang teguh pada prinsip bahwa kehidupan yang seyogyanya adalah kehidupan yang selaras dengn segala iklim keseimbangan alam semesta ini yang terisi kekuatan gaib. Sehingga terjadinya suatu pelanggaran dapat dianggap sebagai sebab pembawa malapetaka (sial) bagi suatu negri. ${ }^{27}$

\footnotetext{
${ }^{26}$ Ibid., h. 23

${ }^{27}$ Ibid., h. 24
} 


\section{Tahkím}

Vol. XIV, No. 2, Desember 2018

\section{Sanksi Langsung}

Sansksi langsung dilakukan daam hal pandangan hidup masyarakat yang bersifat kongkrit artinya mereka menghendaki adanya kenyataan dan kefaktaan. Sebagai akibatnya setiap pelaksanaan sanksi terhadap pelaku dilakukan secara pelaksanaan sanksi terhadap pelaku dilakukan secara terang- terangan dan terbuka di hadapan umum sebagai satu kenyataan yang telah terjadi Bentuk-bentuk sanksi adat bagi negeri yang melakukan penyelewengan berupa pelanggaran ataupun kejahatan terhadap kesepakatan perjanjian perdamaian dalam kedua negeri yang bertikai misalnya, Terjadinya musibah (sial) bagi negeri yang tidak mentaati kesepakatan damai tersebut. Seperti meninggalnya warga masyarakat tanpa sebab yang elas dan wabah penyakit akan melanda negeri yang bersangkutan. Sehingga perlu dilakukan upacaraupacara adat tertentu sebagai penebus atas kesalahan yang dilakukan seperti, cuci negeri dan tolak bala. Dengan demikian, maka sanksi yang diberikan kepada negeri yang melakukan penyelewengan berupa pelanggaran dan kejahatan terhadap kesepakatan pemerintah dan latupati tersebut juga ditindak sesuai hukum negara melalui proses peradilan. ${ }^{28}$

\section{Dampak Konflik Terhadap Perekonomian Masyarakat di Negeri Mamala dan Morella}

Masalah perekonomian yang timbul sesuai dengan dugaan penulis, dampaknya adalah: Pertama, kemiskinan, adalah dimana korban dari sebuah konflik tersebut menderita kerugian rusaknya fasilitas, penjarahan, bahkan ketika ada anggota keluarga yang terluka maka pengobatan secara pribadi. Kedua, turunya aktifitas perekonomian, dalam hal jual beli akan menurun, dimana adanya rasa trauma akan kepemilikan barang-barang yang telah dijarah, ataupun juga karena keadaan keuangan yang tidak memungkinkan. Ketiga, melonjaknya kebutuhan pokok, keadaan yang belum stabil dimanfaatkan para pedagang untuk menaikan harga kebutuhan pokok.

Dari dampak konflik yang terlihat dapat diketahui adanya perubahan-perubahan yang mencolok dari segi perekonomian ini. Sebagian masyarakat yang berpenghuni diperbatasan antara kedua Negeri tersebut dahulu memiliki rumah bagus, pakaian yang banyak, kendaraan, pliharaan ternak, perabotan rumah tangga, alat elektronik dan assetset berharga lainya kini setelah konflik itu terjadi semua harta benda itu telah minim.

Penurunan aktivitas perekonomian, dalam hal jual beli atau pertanian akan menurun. Adanya rasa trauma akan kepemilikan lahan-lahan perekonomian tersebut. Masyarakat yang menjadi penyebab konflik ini terjadi adalah dikarenakan tingkatan ekonomi yang berbeda, maka kegiatan perekonomian maysarakat menurun secara drastis.

\section{${ }^{28}$ Ibid.}




\section{Tahkím}

Vol. XIV, No. 2, Desember 2018

Konflik Mamala Morela mungkin akan mengalami perubahan dari konflik yang berskala kecil menjadi konflik dalam skala yang lebih besar pada waktu-waktu yang akan datang apabila penegakan hukum tidak memberikan efek jerah terhadap kedua masyarakat yang bersangkutan, sehingga jika konflik tersebut lebih berada pada skala yang besar maka sudah barang tentu roda perekonomian yang dijalankan oleh pelaku ekonomi sangatlah mengalami kendala dalam hal jual beli.

Perekonomian yang ada pada kedua Negeri yang berada di bawah pemerintahan Kecamatan Leihitu Kabupaten Maluku Tengah yakni negeri Mamala dan Morela sebelum konflik, masyarakat sangat jauh dari keterpurukan ekonomi, kemakmuran Mamala maupun Morela dalam perekonomian memberikan hal positif dalam masalah pembangunan infrastruktur, pendidikan sangat berjalan dengan baik di kedua Negeri tersebut, namun setelah terjadinya konflik, perbedaan terjadi sangat drastis terutama pada perekonomian seperti pedagang kaki lila, tukang ojek, supir angkot, dan petani. Pendapatannya jauh berbedah atau mungkin saja lumpuh.

Sejalan dengan itu, konflik tidak hanya menggangu kehidupan sosial bermasyarakat, namun lebih dari itu, konflik juga dapat memberikan efek negatif terhadap perekonomian masyarakat sehingga kebutuhan masyarakat yang berada pada lingkaran perekonomian menjadi lumpuh akibat konflik yang berkepanjangan, hal tersebut dapat kita jumpai di Maluku secara umum dan khususnya konflik yang terjadi antara negeri Mamala dan Morela.

Letak geografis antara kedua wilayah yang begitu dekat membuat mereka dengan mudah melakukan proses jual beli atau pun proses kebutuhan hidup yang lebih cenderung kepada kegiatan ekonomi seperti, proses transportasi, perdagangan dan pertanian. Perdagangan yang dimaksud di sini adalah proses jual beli barang-barang sembako yang dilakukan oleh pedagang kaki lima. Selanjutnya proses transportasi yang dimaksud adalah tranportasi darat, yaitu angkutan-angkutan umum (roda empat dan roda dua). Sedangkan proses perekonomian dibidang pertanian adalah proses jual beli hasil alam antara masyarakat Mamala dan Morela. Hasil alam yang dimaksud adalah cengkih, pala, manggis, durian, lansa, kelapa, sayur-sayuran dan tanaman umur pendek lainnya. Hal ini sesuai dengan pernyataan salah seorang informan bahwa "aaat konflik, katong bajual ini paleng stenga mati, yang dulunya katong pung pendapatan keuntungan jual ikan, 1 hari bisa dapat sampe Rp.100.000 s/d Rp.250.00. tapi setelah konflik, katong pung pendapatan itu, akang paling menurun, mau dapa Rp. 100.000 jua mar susah." 29

Penjelasan di atas, menunjukkan, bahwa sebelum konflik, pendapatan masyarakat dapat menunjang kehidupan keluarga, namun saat konflik yang terjadi antara masyarakat Mamala dan Morela, sangatlah memberikan kerugian bagi pendapatan masyarakat salah satunya dalam proses jual beli hasil laut (ikan). Jelasnya,

${ }^{29}$ Wawancara dengan Nurma Latukau (Jibu-Jibu), tanggal 11 Mei 2016 


\section{Tahkím}

Vol. XIV, No. 2, Desember 2018

sebagian masyarakat Mamala memiliki mata pencarian dari usaha jual-beli hasil laut yang dapat menopang kebutuhan keluarga sehari-hari serta sebagai bagian dari poros perekonomian Negeri Mamala.

Begitupun dari segi tranportasi darat sangatlah mempengaruhi pendapatan mereka yang bekerja sebagai supir atau pengumudi angkutan umum, dan juga dalam proses jual beli barang-barang sembako dan hasil alam lainnya, seperti yang di sampaikan oleh salah seorang informan bahwa "konflik ini katong pendapatan paleng kurang, bahkan mau dapa Rp. 50.000 jua paleng susah terutama bagi katong yang tukang ojek, begitupun deng katong pung sudarah-sudarah yang karja sebagai supir oto karena penumpang susah dan juga sudara-sudara lain yang berjualan (pedagang)." 30

Dari penjelasan tersebut dapat diketahui bahwa, konflik memberikan kegagalan serta keterpurukan dalam menjalani roda perekonomian kedua masyarakat Negeri Mamala dan Morela. Bukan saja bidang perekonomian, tetapi hubungan antara kedua masyarakat pun sangat renggang. Apalagi pola perekonomian masyarakat Negeri Mamala ditopang oleh tranportasi darat dengan menggunakan kendaraan beroda dua dan beroda empat yang merupakan mata pencaharian sebagai penjawab kebutuhan hidup keluarga atau pun pribadi.

Adapun proses perekonomian masyarakat Negeri Morela pada bidang hasil pertanian salah satunya rempah-rempah yang umum di jumpai di Maluku secara keseluruhan dan khususnya di Negeri Morela. Cengkih juga merupakan hasil pertanian yang menjadi primadona yang bukan saja bagi masyarakat Negeri Morela tetapi juga Maluku secara keseluruhan sebagai salah satu elemen terpenting dalam menunjang kebutuhan serta pendapatan dalam menghidupi keluarga ataupun pribadi.

Namun di lain sisi konflik tersebut memberikan dampak positif bagi sebagian masyarakat. Dalam hal ini sebagaian masyarakat Morela yang melakukan proses perekonomian tranportasi laut yang dapat memberikan keuntungan bagi mereka. Hal ini karena, sebelum terjadinya konflik masyarakat Morela tidak ada yang melakukan perjalanan dengan menggunakan transportasi laut (spit). akan tetapi setelah konflik terjadi, kecenderungan masyarakat morela dalam melakukan perjalanan ke wilayahwilayah yang di luar dari Morela lebih menggunakan transportasi laut (sped boad) sehingga keuntungan pun lebih menyentuh kepada mereka yang berprofesi sebagai penegmudi spit tersebut.

Tetapi sebagian masyarakat bahkan hampir semua masyarakat Morela menyampaikan keluhan mereka dalam melakukan perjalanan dengan menggunakan trasportasi laut. Karena harga yang ditetapkan lebih tinggi dari harga transportasi darat. Fenomena tersebut sesuai dengan penjelasan informan bahwa "memang konflik di sisi lain sangat memberikan kerugian bagi katong masyarakat morela, namun di lain sisi juga, konflik tersebut memberikan keuntungan par katong masyarakat sebagaian

\footnotetext{
${ }^{30}$ Wawancara dengan Saiful Malawat, (tukang Ojek), tanggal 14 Mei 2016
} 


\section{Tahkím}

Vol. XIV, No. 2, Desember 2018

kelompok yang bawa spit. Karna katong masyarakat seng bisa naik oto seperti dolo sebelum konflik. Tapi masyrakat juga mengeluh karna harga spit yang lebih mahal dari harga oto. Karena sebelum konflik itu katong kalu mau pi kota harga oto cuma Rp. 10.000 tapi skarang ini katong mau pi kota harga spead Rp. 20.000 itu belum sampe di kota lai itu baru d Hitu.",31

Dari penjelasan tersebut, bahwa konflik yang terjadi antara kedua Negeri tersebut adanya memberikan dampak positif bagi sebagian orang dari Negeri Morela, akan tetapi dampak negatifnya lebih banyak dirasakan oleh masyarakat akibat dari harga transportasi darat yang lebih tinggi dari harga laut transportasi.

\section{Kesimpulan}

Berdasarkan uraian di atas dapat ditarik beberapa kesimpulan sebagai berikut:

1. Negeri Mamala dan negeri Morela secara historis merupakan satu kesatuan sosial genelogis, yang mempunyai leluhur yang sama. Kedua wilayah ini harus di pahami sebagi "ujung negeri'" dan bukan batas wilayah mamala/atau morela. Dari situ kedua negeri, Mamala dan Morela seharusnya menjadikan itu sebagai modal sosial dan kearifan local serta membangun prespektif baru yang aman dan damai.

2. Faktor yang sangat fundamental hingga menyebabkan konflik negeri Mamala dan Morela sebenarnya adalah fanatisme adat yang berlebihan mengenai siapa yang dahulu tiba di wilayah itu. Dan terdapat beberapa faktor pemicu di antaranya

1) Maraknya minuman keras (miras), yang beredar dalam kedua negeri

2) Kenakalan remaja

3) Masalah adat 'tradisi baku pukul manyapu',

4) Tidak efektifnya peneyelasaian hukum oleh pemerintah

3. Dampak konflik terhadap perekonomian masyarakat Mamala dan Morela dapat dilihat pada jalur transportasi laut dan darat. Konflik telah menyisakan dampakdampak buruk bagi masyarakat kedua negeri, ketidak stabilan kehidupan sosial, ekonomi dan pendidikan. Masyarakat Morela yang lazimnya harus menjalankan roda perekonomiannya terpaksa harus melewati jalur transportasi laut yang secara material memakan biaya yang cukup mahal, begitupun para pelajar dan mahasiswa. Dampak-dampak ini secara fundamental, telah mengganggu kejiwaan masyarakat khususnya remaja dan pemuda-pemuda kedua masyarakat yang pada ahirnya menimbulkan perasaan dendam, kecemburuan, saling curiga dan lain sebagainya yang suatu saat dapat menimbulkan konflik.

\footnotetext{
${ }^{31}$ Wawancara dengan M. Rahmat Benyal tanggal 04 Juni 2016.
} 


\section{Tahkím}

Vol. XIV, No. 2, Desember 2018

\section{DAFTAR PUSTAKA}

Francis, Abraham M. Moderenisasi di Dunia Ketiga Suatu Teori Umum Pembangunan, Yogyakarta: Tiara Wacana Yagya, 1991.

Galtung, Johan. Studi Perdamaian, Perdamaian dan Konflik, Pembangunan, Pembangunan dan Peradaban, Surabaya: Aliansi Penerbit Interpenden, 2003

Haupea, Supiyat. Modal Social dalam Penyelesaian Konflik, Studi Tentang Resolusi Konflik antar Desa di Kecamatan Leihitu. Tesis Tidak diterbitkan, 2008.

Jamil, Mukhsin M. Mengelola Konflik Membangun Damai, Teori Strategi dan Implementasi Resolusi Konflik.

Malawat, Haris. Hubungan antara Negeri Mamala dan negeri Morela di Jazirah Leihitu Pulau Ambon, (Skripsi), 1994.

Mas'udi, Farid Masdar. Agama dalam Konflik Sosial, dalam M.Imdadun Rahmat, Islam Pribumi: Mendialogkan Agama Membaca Realitas, Jakarta: Erlangga, 2003.

Minako, Sakai. Konflik sekitar Devolusi Kekuasaan Ekonomi dan Politik: Suatu Pengantar, The University of New South Wales, 2005.

Sahalessy, J. "Peran Latupati Sebagai Lembaga Hukum Adat," Jurnal Sasi, Vol. 17 No. 3, 2011

Sahetapi, J. "Lembaga Latu Pati Sebagai Lembaga Hukum Adat dalam Penyelesaian Konflik di Kecamatan Leihitu." Jurnal Sasi, Vol. 17, No. 3, 2011

Syaukani, Imam. "Hakikat Hukum Islam:Antara Divine Law Dan Man-Made Law," Ulumuddin, Vol. VI, Tahun IV, Januari-Juni, 2010.

Soekanto, Soejono. Pengantar Sosiologi Kelompok, Bandung: Remaja Rosda Karya, 2006.

Syani, Abdul. Sosiologi Kelompok dan Masalah Sosial, Cet.2; Jakarta: Fajar Agung, 1987.

Waileruni, Samuel. Membongkar Konspirasi di Balik Konflik Maluku, Jakarta: Yayasan Pustaka Obor Indonesia, 2011.

Waluyo, Mudji. Implementasi Polisi Mitra Masyarakat dalam Merajut Damai Mamala-Morela. Jurnal Sasi, Vol. 19, No. 03, 2013. 